\title{
Dorian Gray’s Spiritual Ecological Crisis and the Inspiration to Modern People
}

\author{
Junhong Tang1, Wei Zhang ${ }^{2}$ \\ ${ }^{1}$ Foreign Language Department, Baoding University, Baoding, China \\ ${ }^{2}$ Educational Administration, Jibei Baoding Electric Power Vocational and Technology College, Baoding, China \\ Email: jessy09012003@yahoo.com.cn
}

Received February $8^{\text {th }}, 2013$; revised March $11^{\text {th }}, 2013$; accepted April $3^{\text {rd }}, 2013$

Copyright (C) 2013 Junhong Tang, Wei Zhang. This is an open access article distributed under the Creative Commons Attribution License, which permits unrestricted use, distribution, and reproduction in any medium, provided the original work is properly cited.

\begin{abstract}
As an individual of spiritual existence, Dorian Gray, in The Picture of Dorian Gray, lacked the ability to love his lovers and friends, lost the normal aesthetic ability, failed to control his gradually increasing evil desires, so his body and soul began to go far away step by step. The imbalance and instability of his spiritual factors like love ethic, moral ethic, aesthetic ethic and life ethic led to the completely collapse of Dorian's spiritual ecological system, even to his suicide. Dorian's spiritual ecological crisis inspires the modern people a lot. It provides people with a full view of their own life style, stimulates people to pay more attention to their own spiritual ecological system, and spurs modern people on to adjust their spiritual factors in the right orbit of balance and stability. The government and the public media are supposed to play their part in keeping citizens well-informed of the potential benefit of the normal spiritual ecological system. Only does a person's spiritual ecological system runs in order, he can live normally and make contributions to others, to the society.
\end{abstract}

Keywords: Love; Desire; Aesthetic Ability; Dorian Gray; Spiritual Ecological Crisis; Modern People

\section{Introduction}

In The Space for Eco-criticism, professor Lu Shuyuan mentions that except for social and natural ecology a person is also a kind of spiritual ecology in terms of the living conditions of human beings ( $\mathrm{Lu}, 2006)$. The spiritual ecology refers to the balance and stability of the spiritual ecological factors such as love ethic, moral ethic, aesthetic ethic, life ethic, etc. Moreover, the spiritual ecological system is the necessary premise and basis of the natural ecological and the social ecological system. Once the balance and the stability of the spiritual factors are disturbed, the spiritual ecological system of a person will be thrown into disorder. Then the spiritual ecological crisis will come into being and the crisis will lead the person to be immoral, abnormal and far away from the right orbit of life. The spiritual ecological crisis of Dorian Gray, the protagonist in The Picture of Dorian Gray, was demonstrated clearly and in detail. Taking drugs, enjoying excessively, committing suicide are the obvious and important signals of Dorian's spiritual ecological crisis. In British literature, the comments on Oscar Wilde, the author of The Picture of Dorian Gray, vary from one person to another. People who like and admire Oscar think he is a talented genius, while people who dislike and disgust him consider him as a joke and an abnormal person. To some extent, the life style of Dorian Gray in The Picture of Dorian Gray was a mirror of Oscar Wilde's own life.

In spiritual ecological system, love is as important as the sunshine and air in the natural ecological system. Only is there love, the spiritual ecological system can develop healthily. Aesthetic ability is like the mountains and rivers in the spiritual ecological system, so each person is supposed to reclaim, to use and to preserve it reasonably and properly. Desire is the food and water of the spiritual ecological system, and suitable supply can maintain the system runs in order, otherwise it will collapse. In The Picture of Dorian Gray, the spiritual ecological crisis of Dorian Gray, as the spiritual existence, is demonstrated in the lack of s love ability, the lost of aesthetic ability and the disability of controlling his evil desires. So Dorian Gray's spiritual ecological system is doomed to collapse.

\section{Lack of the Ability of Love}

Each person is expected to learn and master many abilities in the daily life, of which love ability is the most important while the most difficult to possess. In The Art of Loving, Erich Fromm states that only does a person have the ability to love, then he is able to love others (Fromm, 1987). Unfortunately, Dorian Gray, in The Picture of Dorian Gray, failed to have the ability to love, so he not only showed indifference and hard-heart in response to his lover's affectionate love, but also disliked even murdered his only real friend Basil Hallward. In spiritual ecological system, love is as indispensable as the sunshine and the air. Any system which lacks sunshine and air is doomed to collapse step by step. It was very difficult for us to find love in Dorian Gray’s spiritual ecological system, so his spiritual ecological system was certain to fall down.

\section{Lack of Love Ability in Making Lovers}

Dorian Gray found 17-year-old Sibyl Vane by chance in a 
small and poor theater. Dorian was so deeply attracted by the actress' beautiful appearance and her excellent performance on the stage that he fell in love wither her and proposed to her very soon. Sibyl Vane also thought she had found the real lover in her life and she considered it would be profanation for her to play at being in love. So she decided to go away from the stage and enjoy the true love fully and deeply. However, Dorian Gray, whose spiritual ecological system failed to possess the love ability, was not able to appreciate Sibyl's true love for him. "He flung himself down on the sofa and turned away his face. 'You have killed my love,' he muttered.” (Wilde, 2007) A last Dorian said to Sibyl Vane in his calm clear voice. "I don't wish to be unkind, but I can't see you again. You have disappointed me." (Wilde, 2007) Sibyl Vane was hurt so deeply that she committed suicide on the right night that Dorian Gary broke up with her. On hearing the death of his lover, Sibyl Vane, Dorian did not blamed himself, did not felt regretful, but did think Sibyl's was another beauty. "There is something of the martyr about her. Her death has all the pathetic uselessness of martyrdom, all its wasted beauty.” (Wilde, 2007) It is easy for us to make a conclusion that Dorian Gray did not take love seriously, did not cherish his lover carefully and did not know what is true love and true love was far away from him.

Later, Dorian met the countryside girl, Hetty Merton. But Dorian hurriedly said goodbye to Hetty because of his so-called reason that he did not want to hurt her. However, the real reason was absolutely not what he claimed to be but for his own vanity. Dorian wanted his portrait to appear the same as before. "As he thought of Hetty Merton, he began to wonder if the portrait in the locked room had changed... Perhaps if his life became pure, he would be able to expel every sign of evil passion from the face. Perhaps the signs of evil had already gone away. He would go and look.” (Wilde, 2007) In order to satisfy his personal purpose, Dorian hurt another girl once again.

Dorian's indifference and selfishness caused him not to know how to deal with his love and how to cherish his lovers, so he did not get married even in his 40s. Ridiculously, his life was full of flirtation and love affairs. It proved that true love was absent in Dorian Gray's life and Dorian Gray did not possess the ability to love his lovers at all.

\section{Lack of Love Ability in Making Friends}

The more the friends, the more the happiness and warmness are right to a normal person whose spiritual ecological system contains the spiritual factor of love. While this idea is not true to Dorian Gray, because his spiritual factor of love was completely distorted in his spiritual ecological system and his spiritual ecological system had run disorderly. Reading the novel, we could see Basil was the only true friend of Dorian. Basil was concerned about Dorian's life and was also worried about Dorian would be affected by Henry's immoral life ethics. Dorian himself also acknowledged that Basil always made some advice on him. "I don't want to see him alone. He says things that annoy me. He gives me good advice.” (Wilde, 2007) Basil's good advice on Dorian became a kind of invisible monitor and control. Just as bitter medicine cures sickness, so unpalatable advice benefits conduct. But Dorian did not realize it, he did not like Basil's advice on him and he decided to go out of Basil's monitor and control. When Basil prayed for him after Basil saw his ugly soul, Dorian killed Basil. "He rushed at him and dug the knife into the great vein that is behind the ear, crushing the man's head down on the table and stabbing again and again.” (Wilde, 2007) A friend in need is a friend indeed. Basil tried his best to help Dorian Gray, but Dorian could not appreciate what Basil had done for him and killed Basil under the drive of evil desire of running out of Basil's monitor and control.

Dorian slept soundly on the right night on which he killed his only true friend, Basil. Dorian had become so abnormal that he did not know what love is, what friendship is and even what a human being is. He failed to love his lovers, his friends and the people around him. The lack of spiritual factor of love predicted that Dorian's spiritual ecological system could not develop in the right way, because love in the spiritual ecological system is like the sunshine and air in the natural ecological system. Any natural ecological system which lacks sunshine and air will collapse in the dark and any spiritual ecological system which excludes love will die in the numb.

\section{Lost of the Aesthetic Ability}

The forms of goodness are various. Goodness not only refers to good looks, beautiful postures and expensive clothes ( $\mathrm{Li}$, 2011). The more important things for goodness are noble souls, polite behaviors and excellent character. The person who only pays much attention to the external goodness like good looks, beautiful postures and expensive clothes generally tends to fall into the pursuit of luxurious enjoyment, completely regardless of his contribution and repayment to the society. Dorian Gray, in The Picture of Dorian Gray, was so infatuated with good looks, beautiful posture and the expensive clothes all the time while noble soul, polite behavior and excellent character seemed to have nothing to do with him.

"I know, now, that when one loses one's good looks, whatever they may be, one loses everything... Youth is the only thing worth having. When I find that I am growing old, I shall kill myself.” (Wilde, 2007) In Dorian's opinion, good looks was the most important thing in his life. Without the external goodness, he could not live any longer. So, it is difficult for us to see any trait of the internal goodness in him. Just because of Dorian's this kind of life ethic, he spent so much time on the place he live, the goods he used and the clothes he wore. Even on the next morning on which he killed Basil the day before, Dorian pay more attention to the clothes what he was going to wear. "Dressed himself with even more than his usual care, giving a good deal of attention to the choice of his necktie and scarf-pin and changing his rings more than once.” (Wilde, 2007) The decorations of his living place were also very luxurious. "In the huge gilt Venetian lantern, spoil of some Doge's barge that hung from the ceiling of the great, oak-paneled hall of entrance, lights were still burning from three flickering jets: thin blue petals of flame they seemed, rimmed with white fire." (Wilde, 2007) Dorian's little dinners were also well known because the persons on his invitation list were carefully elected and the tables, the exotic flowers, and the gold and silver plates were also well chosen.

Dorian Gray, who care so much about the clothes he wore, the place he lived, the things he used, did not dare to face up with his own portrait, which symbolized his ugly soul, his bad behaviors and his distorted character. 
Table 1.

The illustration of the splitting up of Dorian's body and soul.

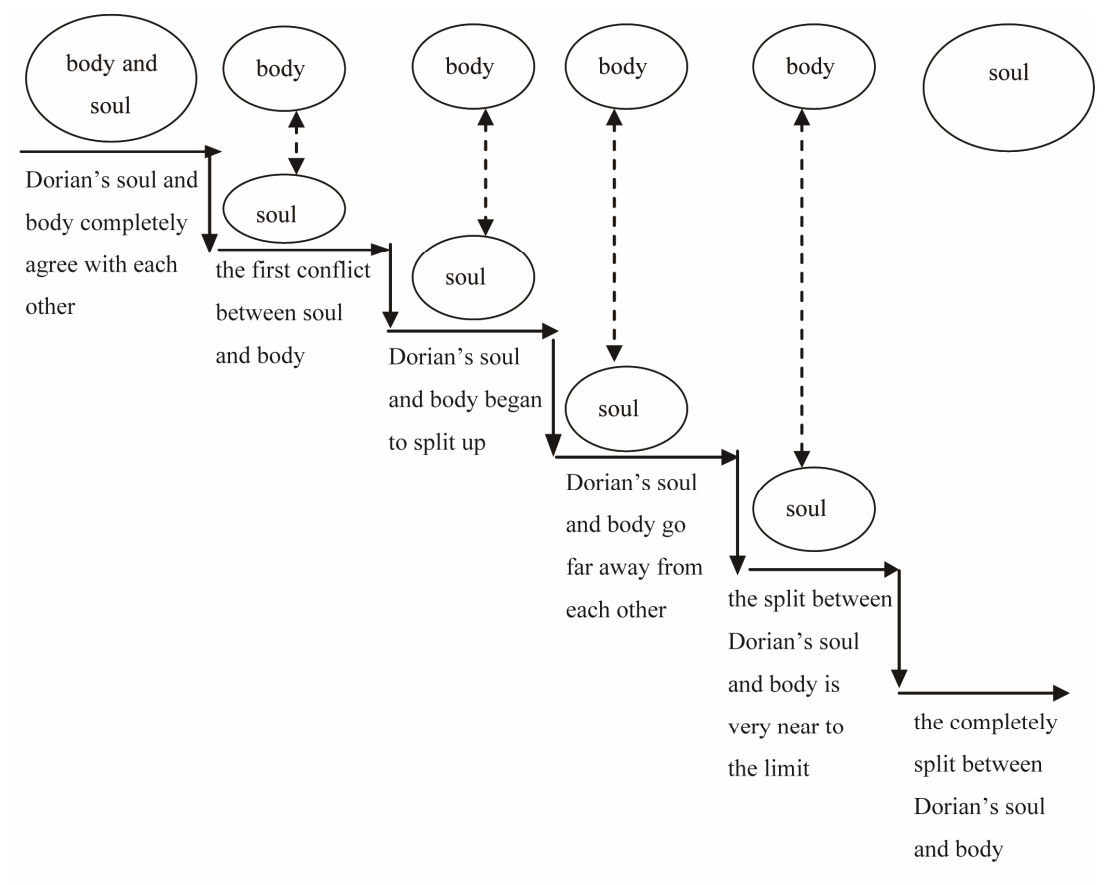

\section{Dorian was naive \\ and kind-hearted \\ before he met Henry

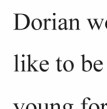 \\ regardless of \\ betraying his \\ soul \\ Dorian's Body and Soul Split up Gradually under the Drive of His Evil Desires}

In The Picture of Dorian Gray, Dorian Gray’s spiritual ecological system went to collapse step by step, which can be shown in Table 1.

In Lacan's opinion, the social atmosphere is very important in the process of moulding a person's character (Lacan, 1977). In The Picture of Dorian Gray, Dorian Gray's soul and body were perfectly agree with each other and his spiritual ecological system was in complete harmony before Dorian Gray met Henry, who put excessive enjoyment on the first place. Unfortunately, Dorian Gray met Henry and later they kept in close touch with each other. So the naïve and kind-hearted Dorian Gray was corroded dreadfully under the influence of Henry's words, ideas, and behaviors since Dorian Gray became acquainted with Henry. Under the drive of being young forever, inspired by Henry's life ethic, Dorian Gray produced the vicious idea that how wonderful it would be if the picture would become old on his behalf. "If it were I who was to be always young, and the picture that was to grow old! For that-for that-I would give everything! Yes, there is nothing in the whole world I would not give! I would give my soul for that!” (Wilde, 2007) It was the first time that the evil desire came into Dorian Gray's mind. Dorian would like to sell his soul for his so-called "always young" which means maintaining beautiful

\section{Dorian killed Dorian forced Dorian's knife \\ Basil under the Campbell to help which pointed \\ desire of go him destroy all to the picture \\ out of monitor the evidence and came into a \\ and control later caused own body \\ Campbell}

com-mitted suicide

appearance forever. Proper desire is one of the necessities of each person, but it will be dangerous and destroyable to any person if the person's desire is released more than what is normal or necessary. Desire is the food and water of a person's spiritual ecological system. The suitable provision will keep the system run in order and develop healthily, but excessive supply of food and water will destroy the system.

"What did it matter what happened to the colored image on the canvas? He would be safe. That was everything. He drew the screen back into its former place in front of the picture, smiling as he did so...” (Wilde, 2007) From this kind description we knew Dorian Gray absolutely enjoyed his beautiful appearance no matter what change would happen on the canvas. And he also began to appreciate his good external appearance regardless of his internal degrading soul which was obviously shown on the evil and aging face on the canvas. "....and stand, with a mirror, in front of the portrait that Basil Hallward had painted of him, looking now at the evil and aging face on the canvas, and now at the fair young face that laughed back at him from the polished glass. The very sharpness of the contrast used to quicken his sense of pleasure.” (Wilde, 2007)

Dorian Gray fell into the whirlpool of excessively enjoyment under the cover of his external beautiful appearance and the bad influence of Henry. Dorian's evil desire was released too much to be controlled and the vicious desire gradually became so strong to have the power over his body. The distance between 
Dorian's soul and body went farther and farther.

Suitable personal desire is the necessary basis for a person to live, and it is also the premise for the society to develop, so the suitable desire is moral and preferred. But excessive evil desire will be dangerous and destroyable to others, to the society, so it is immoral ( $\mathrm{Li}, 2005)$. “To see my soul!' muttered Dorian Gray, starting up from the sofa and turning almost white from fear.” “'YYes,' answered Hallward gravely, and with deep-toned sorrow in his voice, "to see your soul. But only God can do that.", "A bitter laugh of mockery broke from the lips of the younger man. 'You shall see it yourself, to-night!' he cried.” (Wilde, 2007) After enjoying so many sweet experiences under the cover of the external beautiful appearance, Dorian Gray's evil desire became inflated infinitely day by day. In order to conceal his own ugly soul, Dorian Gray killed his only true friend who had seen his bad soul under the drive of his inflated evil desire. "He (Dorian Gray) rushed at him (Basil) and dug the knife into the great vein that is behind the ear, crushing the man's head down on the table and stabbing again and again." (Wilde, 2007)

Dorian Gray who had lost his senses under the control of evil desire wanted to destroy all the evidence which recorded his murder. In order to satisfy his bad desire, Dorian Gray though of Alan Campbell, a promising and talented young man who locked himself all the day in his laboratory to focus on his chemistry. Alan Campbell was forced to promise to help Dorian Gray destroy all the evidence. At the same time, something changed on the canvas. "What was that loathsome red dew that gleamed, wet and glistening, on one of the hands, as though the canvas had sweated blood?" Later Campbell committed suicide because he could not bear the tortures of his guilty conscience. In such a way, Dorian killed Campbell indirectly, but his conscience was not troubled at all.

Desire is the motivation to a person's development, and it is also the origin of a person's spiritual ecological crisis (Wang, 2011). The changes of the picture were the records of Dorian's excessive release of evil desire. In order to meet his inflating vicious desire of destroying any bad evidence, Dorian Gray, whose spiritual ecological system had completely collapsed, grabbed the knife, which had killed Basil, and pointed it to the picture. With a horrible cry in its agony, the knife stabbed into Dorian Gray's body. Lying on the floor, in evening dress, he was withered, wrinkled, and loathsome of visage, while the portrait was in all the wonder of his exquisite youth and beauty. Dorian's body died. Dorian's soul revived. Dorian's soul and body split up completely.

\section{The Inspiration of Dorian's Spiritual Ecological Crisis to the Modern People}

With the rapid development of science and technology, on one hand people's material living standard has been improved to a great extent, but on the other hand people's spiritual living standard has not been cultivated at the same level. Some statistics and reports show that more and more people's spiritual factors are not in the state of balance and stability. Thus their spiritual ecological systems do not run in the right orbit.

\section{Dorian's Spiritual Ecological Crisis Makes Modern People Review Their Own Life Style}

In The Picture of Dorian Gray, Dorian Gray indulged himself in the pursuit of keeping up appearances such as handsome appearance, fine clothes and good postures, but he did not cared about his internal goodness at all. To some extent, Dorian's life style in the novel alludes to the life style of some modern people. Individualism, utilitarianism, money worship, and consumerism prevail in some places among some people. Some people would probably become dishonest and greedy for more profit. Empty promises, deception and immoral conducts intensify the conflicts between one person and another. Although the modern people can pick up their mobile phones to call a person at any time, the spiritual distance between one person to another is becoming farther and farther. At present, the cases of committing suicide, taking drugs, divorce, melancholia, extramarital relationship has become more and more obvious. Nowadays so many people are the reproductions of Dorian Gray. It is not difficult for us to make a conclusion that such bad things result from the abnormal spiritual ecological system.

\section{Dorian's Spiritual Ecological Crisis Stimulates People to Pay More Attention to Their Own Spiritual Ecological System}

Dorian Gray's ending up in committing suicide strike fear into our hearts. In order to live longer and happier, we must and have to be fully aware of what we did and what we will do. We must try our best to make our spiritual ecological system run in the right orbit and maintain the balance and stability of the spiritual factors (Shen, 2011). We should appreciate all that our friends did for us and in turn, we are supposed to help our friends when they need our help. We are expected to love our lovers sincerely. The internal goodness like noble soul, polite behaviors and good character is indispensable to each excellent citizen. We should always think about what we can contribute to our family, to the people around us and to the society.

At the same time, the government is expected to make its any effort to improve people's spiritual ecological system; the journalists and the public media are supposed to play their part in this issue: they should keep the citizens well-informed of the potential harm of the abnormal spiritual ecological system; we should be fully aware of what is a real and normal human being. Each human being must and have to own the ability to love his lovers, to love his friends and to love each person around him, gain the correct aesthetic ethic to live a normal life, and obtain the necessary ability to develop our own desire in the right orbit. Only does a person's spiritual ecological system runs in order, he can live normally and make contributions to others, to the society (Liu, 2009).

\section{Acknowledgements}

The paper is under the project of the Importance of Ecological Literature in British and American Literature Teaching (SZ123002). All the project members made their contributions to the paper. I also thank all my friends and classmates who lives in different cities, which made the investigation possible.

\section{REFERENCES}

Fromm, E. (2007). The art of loving. Beijing: The Commercial Press. Lacan, J. (1977). Ecrits: A selection M. Alan Sheridan. London: Tavistock.

Li, C. (2005). On ethics and desires. Journal of Academic Forum, 2, 57-58. 
Li, P. (2011). The improvement of aesthetic culture: The education of drawing provide the basis of character ethics. Journal of New Corses, $1,27$.

Liu, W. L. (2009) On spiritual ecology and social ecology: What we can not ignore. Journal of Theory and Reform, 2, 95-98.

Lu, S. Y. (2006). The room of ecological criticism. Shanghai: East China Normal University Press.
Shen, Y. (2005). On spiritual ecology and ethics. Journal of Guangxi Education College, 2, 100-102.

Wang, N. S. (2011). On desires-The motivation and crisis of people. Journal of Ningbo University of Technology, 3, 6-8.

Wilde, O. (2007) The picture of Dorian Gray. Signet Classics. 